
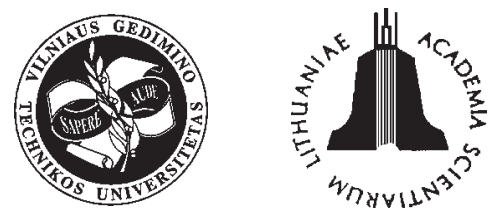

JOURNAL OF CIVIL ENGINEERING AND MANAGEMENT

http:/www.jcem.vgtu.lt

2005, Vol XI, No 4, 309-322

\title{
VISCOELASTIC DAMPER CONNECTED TO ADJACENT STRUCTURES INVOLVING SEISMIC ISOLATION
}

\author{
Vasant Annasaheb Matsagar and Radhey Shyam Jangid \\ Dept of Civil Engineering, Indian Institute of Technology Bombay, Powai, \\ Mumbai-400076 (India).E-mail: rsjangid@civil.iitb.ac.in
}

Received 14 Jan 2005; accepted 20 Sept 2005

\begin{abstract}
The seismic response of multi-storied base-isolated structure to various types of isolation systems connected using viscoelastic dampers to the adjacent dissimilar base-isolated or fixed-base structure is investigated. The multistoried structures are modelled as a shear type structures with lateral degree-of-freedom at each floor, which are connected at different floor levels by viscoelastic dampers. The performance of this combination is studied by deriving the governing equations of motion and solving it in the incremental form using Newmark's step-by-step method of integration. The variation of top floor absolute acceleration of both the buildings and bearing displacement under different real earthquake ground motions is computed to study the behaviour and effectiveness of resulting connected system. It is concluded that connecting the two adjacent base-isolated buildings with the viscoelastic dampers is useful in controlling large bearing displacements in the base-isolated structures thereby eliminating the isolator damages arising due to instability at these large displacements or pounding with adjacent ground structures during earthquakes. The viscoelastic damper connection between adjacent structures is found to be most effective when the adjacent base-isolated and fixedbase buildings are connected. Such scheme is hence useful in upgrading the seismic performance of existing fixed-base structures adjacent to a base-isolated structure.
\end{abstract}

Keywords: adjacent buildings, earthquake, elastomeric bearing, seismic base isolation, sliding system, retrofit, viscoelastic damper.

\section{Introduction}

The base isolation technique is a viable option to protect the strategically important structures such as hospitals, nuclear power plants, bridges and the mounted sensitive equipments from damages caused by earthquakes. The isolation systems placed underneath the structure, increase its lateral flexibility and also increases the effective damping through the energy dissipated. The dynamic response of a base-isolated structure, therefore, is considerably reduced when compared to its counterpart, the fixed-base structure, as documented in the literature available on base isolation [1-3]. In seismic isolation, the fundamental frequency is lowered and kept away from the predominant frequency range of the most earthquake ground motions. Although, with the decreasing frequency, floor accelerations are reduced helping to limit the structure damages, the increased displacement at isolation level calls upon the necessity of maintaining adequate separation gap distance (moat) to accommodate the large bearing displacement. The separation gap requirement in case of base-isolated structure is therefore more than that of the fixed-base structure.

In modern cities, however, due to a high value of land space, limited availability of land and preference to centralised services, there is a tendency to construct the buildings in close proximity without maintaining proper separation gaps. During an earthquake event, these buildings vibrate rigorously and may become a cause for severe damage because of mutual pounding. The 1985 Mexico City and 1989 Loma Prieta earthquakes are the typical examples of the large-scale damage caused by structural pounding. In view of this, the building codes made stringent requirements for base-isolated structures, specifying accommodation of larger bearing displacements during maximum capable earthquakes and the need for supplemental damping devices. In overcoming this dilemma, the present study of this paper suggests the use of viscoelastic damper connections between the adjacent buildings.

The papers reported by Housner et al [4] and Soong and Spencer [5] provide a detailed review of earlier and recent studies made on structural control and supplemental energy dissipation devices and its applications to the seismic protection. To avoid pounding damages the concept of linking adjacent fixed-base buildings is introduced and verified analytically and experimentally by number of researchers [6-13]. However, mitigation of pounding and/or impact damages in case of base-isolated and ad- 
jacent structures through incorporation of damper linkages between them is untried yet. Therefore, it would be interesting to investigate the effectiveness of connecting the base-isolated building with the adjacent building as an alternative for the protection against possible destruction due to pounding because of an inadequate separation gap provided between the two and improving seismic performance of the existing fixed-base buildings.

This paper investigates the advantages of connecting the base-isolated building to the adjacent base-isolated or fixed-base building using viscoelastic dampers. The main objectives of this study are to investigate the dynamic characteristics of base-isolated building connected to the adjacent base-isolated or fixed-base building by discrete linear viscoelastic dampers and propose this scheme for seismic retrofit of existing earthquakeprone fixed-base structures.

\section{Modelling of adjacent structures}

Fig 1 shows the two structural models under consideration depicting multi-degree-of-freedom shear models with rigid floors. Fig 1(a) shows the l-story baseisolated building connected through viscoelastic dampers at different floors to the adjacent $m$-story base-isolated building. In Fig 1(b), a similar viscoelastic damper connected system with the $l$-story base-isolated building mounted on various isolation systems connected to the adjacent $m$-story fixed-base building is shown, along with the schematic of a typical viscoelastic damper. The masses in these models are assumed to be lumped at each floor level and the stiffness is provided by axially inextensible mass-less columns. Both the adjacent connected buildings are assumed to behave linearly elastic and receive the same earthquake ground motion in horizontally. The soil-structure interaction effects are not taken into consideration. For both buildings, the mass at all floor levels is kept constant while the stiffness is varied to achieve the desired fundamental time periods as fixed-base condition. These adjacent buildings are connected at different floor levels by linear viscoelastic dampers to serve as energy dissipation mechanism.

\subsection{Damping devices}

Energy dissipation devices are of different types and may be categorised depending on the type of material used to transform energy such as: viscous, viscoelastic, friction, metallic yielding and magnetic dampers. In viscous and viscoelastic dampers, the viscous/viscoelastic material, in the form of either liquid (silicone or oil) or solid (special rubbers or acrylics), is provided. Friction devices contain interface materials, such as steel-to-steel, copper with graphite-to-steel, or brake pad-to-steel. Metallic yielding devices most commonly use mild steel plates in different shapes and materials such as lead, shape memory alloys etc. The magnetic damper func- tions on the principle of magnetism of fluid particles as seen in the magnetorheological dampers. In the present study, the viscoelastic dampers are investigated for their usefulness in seismic response mitigation when used as connecting linkages between the two adjacent structures.

\subsection{Viscoelastic damper}

The viscoelastic solid materials are used as a means to dissipate energy in viscoelastic dampers [14, 15]. The viscoelastic materials generally used are copolymers or glassy substances. The energy is dissipated through shear deformation of the viscoelastic layers. Its behaviour depends upon vibration frequency, strain levels and temperature. However, the overall behaviour of viscoelastic dampers can be represented by using a spring-dashpot element acting in parallel. The typical viscoelastic damper consists of viscoelastic layers bonded with steel plates or solid thermoplastic rubber sheets sandwiched between steel plates; refer Fig 1(b). While in active state, the relative motion between central and outer plates gives rise to shear deformations in the viscoelastic fluid between these interfaces and consequently the energy is dissipated leading to seismic response mitigation.

\subsection{Damping force}

The force generated in the viscoelastic damper comprises of two components: elastic force and damping force. The elastic force is proportional to the relative displacement between the connected floors, whereas the damping force is essentially proportional to the relative velocity of the piston head with respect to the damper casing. Hence, the damper force can be expressed as

$$
\left\{F_{\mathrm{d}}\right\}=\left[K_{\mathrm{d}}\right]\left\{u_{\mathrm{b}}, u_{1}, u_{2}, \ldots, u_{l}\right\}^{\mathrm{T}}+\left[C_{\mathrm{d}}\right]\left\{\dot{u}_{\mathrm{b}}, \dot{u}_{1}, \dot{u}_{2}, \ldots, \dot{u}_{l}\right\}^{\mathrm{T}},
$$

where $\left\{u_{\mathrm{b}}, u_{1}, u_{2}, \ldots, u_{l}\right\}=\left\{x_{\mathrm{b} 1}, x_{11}, x_{21}, \ldots, x_{l 1}\right\}-$ $\left\{x_{\mathrm{b} 2}, x_{12}, x_{2}, \ldots, x_{l}\right\}$ and $\left\{\dot{u}_{\mathrm{b}}, \dot{u}_{1}, \dot{u}_{2}, \ldots, \dot{u}_{l}\right\}$ are the vectors of relative displacement and velocity between the damper connected floors of the adjacent buildings and the over-dot denotes the derivative with respect to time. The $\left\{x_{\mathrm{b} 1}, x_{11}, x_{21}, \ldots, x_{l 1}\right\}$ and $\left\{x_{\mathrm{b} 2}, x_{12}, x_{22}, \ldots, x_{l 2}\right\}$ are the displacement vectors for the adjacent building floors. Here, the stiffness elements of dampers placed along the height of the adjacent structures is

$$
\left[K_{\mathrm{d}}\right]=\operatorname{diag}\left[k_{\mathrm{db}}, k_{\mathrm{d} 1}, k_{\mathrm{d} 2}, \ldots, k_{\mathrm{d} l}\right],
$$

where $k_{\mathrm{db}}, k_{\mathrm{d} 1}, k_{\mathrm{d} 2}, \ldots . ., k_{\mathrm{d} l}$ are the damper-stiffness coefficients at the different floor levels. In addition, the damper-damping matrix for the array of dampers placed along the height of the adjacent structures is expressed as

$$
\left[C_{\mathrm{d}}\right]=\operatorname{diag}\left[c_{\mathrm{db}}, c_{\mathrm{d} 1}, c_{\mathrm{d} 2}, \ldots, c_{\mathrm{d} l}\right],
$$

where $c_{\mathrm{db}}, c_{\mathrm{d} 1}, c_{\mathrm{d} 2}, \ldots, c_{\mathrm{d} l}$ are the damper-damping coefficients at different floor levels. 

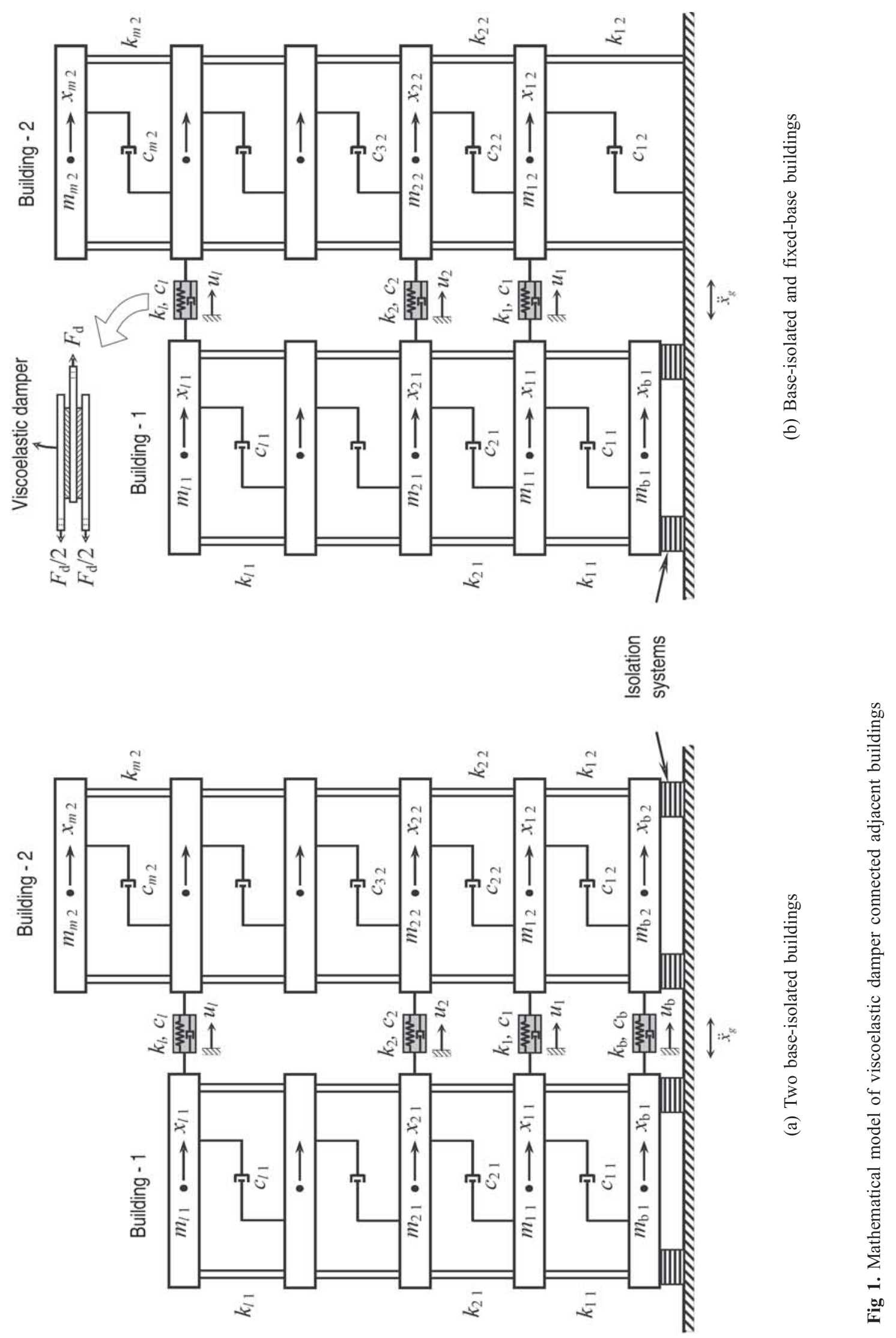
The total external damper-stiffness and external damping added in the form of connection linkages between two adjacent buildings and are expressed respectively as a non-dimensional parameters

$$
\begin{gathered}
\kappa_{\mathrm{d}}=\frac{k_{\mathrm{db}}+\sum k_{\mathrm{d} j}}{\omega_{\mathrm{e}}^{2} \sum M_{\mathrm{i}}} \quad(i=1,2 \text { and } j=1, l), \\
\eta_{\mathrm{d}}=\frac{c_{\mathrm{d} \mathrm{b}}+\sum c_{\mathrm{d}}}{2 \xi_{\mathrm{e}} \omega_{\mathrm{e}} \sum M_{\mathrm{i}}} \quad(i=1,2 \text { and } j=1, l),
\end{gathered}
$$

where $M_{\mathrm{i}}=\left(m_{\mathrm{bi}}+\sum_{j=1}^{l \text { or } m} m_{\mathrm{ji}}\right)$ is the total mass of the base-isolated building; $m_{\mathrm{ji}}$ is the mass of $j^{\text {th }}$ floor of $i^{\text {th }}$ building; $\omega_{\mathrm{e}}$ is the equivalent isolation frequency considered as $\pi \mathrm{rad} / \mathrm{sec}$; $\xi_{\mathrm{e}}$ is the equivalent viscous damping ratio taken as $10 \%$. This implies that the total external damper-damping and damper-stiffness is expressed in proportion with properties of an equivalent linear viscous rubber isolation system having damping ratio of $10 \%$ and isolation time period of $2 \mathrm{sec}$.

\section{Governing equations of motion}

For the systems under consideration, the governing equations of motion are obtained by considering equilibrium of forces at the location of each degree-of-freedom during seismic excitations. Two individual cases of governing equations of motion for such systems under earthquake excitation are given below.

\subsection{Unconnected building systems}

When the adjacent buildings are not connected with any link, they act independently and, for such unconnected base-isolated buildings, the following two sets of governing equations of motion can be obtained, which are of order $l$ and $m$, the degrees-of-freedom for adjacent base-isolated Buildings 1 and 2, respectively under earthquake excitation

$$
\left[M_{1}\right]\left\{\ddot{x}_{1}\right\}+\left[C_{1}\right]\left\{\dot{x}_{1}\right\}+\left[K_{1}\right]\left\{x_{1}\right\}+\left\{F_{\mathrm{b} 1}\right\}=-\left[M_{1}\right]\left\{r_{1}\right\}\left(\ddot{x}_{\mathrm{g}}\right),
$$

$\left[M_{2}\right]\left\{\ddot{x}_{2}\right\}+\left[C_{2}\right]\left\{\dot{x}_{2}\right\}+\left[K_{2}\right]\left\{x_{2}\right\}+\left\{F_{\mathrm{b} 2}\right\}=-\left[M_{2}\right]\left\{r_{2}\right\}\left(\ddot{x}_{\mathrm{g}}\right)$,

where $\quad\left[M_{1}\right]=\operatorname{diag}\left[m_{11}, m_{21}, \ldots, m_{l 1}\right]$, $\left[M_{2}\right]=\operatorname{diag}\left[m_{12}, m_{22}, \ldots, m_{m 2}\right]$ are the mass matrices, $\left[C_{1}\right],\left[C_{2}\right]$ are the damping matrices, $\left[K_{1}\right]$ and $\left[K_{2}\right]$ are the stiffness matrices; $\left\{r_{1}\right\},\left\{r_{2}\right\}$ are the vectors of influence coefficients; $\left\{x_{1}\right\}=\left\{x_{11}, x_{21}, \ldots, x_{l 1}\right\}^{\mathrm{T}}$, $\left\{x_{2}\right\}=\left\{x_{12}, x_{22}, \ldots, x_{m 2}\right\}^{\mathrm{T}},\left\{\dot{x}_{1}\right\},\left\{\dot{x}_{2}\right\},\left\{\ddot{x}_{1}\right\}$ and $\left\{\ddot{x}_{2}\right\}$ are the unknown floor displacement, velocity and acceleration vectors for two adjacent Buildings 1 and 2, respectively; $\ddot{x}_{\mathrm{g}}$ is the earthquake ground acceleration. Here, the second subscripts, $i=1$ and 2 denotes the quantities pertaining to the connected Buildings 1 and 2 adjacent to each other, respectively. $\left\{F_{\mathrm{b}_{1}}\right\}$ and $\left\{F_{\mathrm{b}_{2}}\right\}$ are the isolation layer forces for three different types of isolation systems used in the present study namely, highdamping rubber bearings (HDRB), lead-rubber bearings (LRB) and friction pendulum systems (FPS), placed under the base-isolated buildings. For a fixed-base building, the corresponding isolation force $\left\{F_{\mathrm{bi}}\right\}=0$ in the above governing equations of motion with appropriate modifications in the mass, stiffness and damping matrices.

\subsection{Connected building system}

Owing to the introduction of viscoelastic dampers as connecting links at superstructure of the two adjacent buildings, it converts to a connected isolated system with $(l+m)$ lateral degrees-of-freedom. The governing equilibrium equations of order $(l+m)$ for such a connected system can be obtained from eqs (1), (6) and (7) as

$$
[M]\{\ddot{x}\}+[C]\{\dot{x}\}+[K]\{x\}+\{F\}=-[M]\{r\}\left(\ddot{x}_{\mathrm{g}}\right),
$$

where $\{x\}=\left\{x_{11}, x_{21}, \ldots, x_{l 1}, x_{12}, x_{22}, \ldots, x_{m 2}\right\}^{\mathrm{T}},\{\dot{x}\}$ and $\{\ddot{x}\}$ are the unknown floor displacement, velocity and acceleration vectors for the adjacent connected Buildings 1 and 2, respectively; $\{r\}=\left\{\left\{r_{1}\right\},\left\{r_{2}\right\}\right\}^{\mathrm{T}}$. In eq (8) the mass matrix, $[M]$ for the combined system is obtained by

$$
[M]=\left[\begin{array}{cc}
{\left[M_{1}\right]} & {\left[O_{1}\right]} \\
{\left[O_{2}\right]} & {[M]_{2}}
\end{array}\right],
$$

where $\left[M_{1}\right]$ and $\left[M_{2}\right]$ are the individual diagonal mass matrices for the adjacent Buildings 1 and 2, respectively; $\left[O_{1}\right]$ and $\left[O_{2}\right]$ are the null matrices of order $(l \times m)$ and $(m \times l)$, respectively. The stiffness matrix for the connected system is expressed as

$$
[K]=\left[\begin{array}{cc}
{\left[K_{1}\right]} & {\left[O_{1}\right]} \\
{\left[O_{2}\right]} & {\left[K_{2}\right]}
\end{array}\right]+\left[\begin{array}{rrr}
{\left[K_{\mathrm{d}}\right]} & -\left[K_{\mathrm{d}}\right] & {\left[O_{3}\right]} \\
-\left[K_{\mathrm{d}}\right] & {\left[K_{\mathrm{d}}\right]} & {\left[O_{4}\right]} \\
{\left[O_{5}\right]} & {\left[O_{6}\right]} & {\left[O_{7}\right]}
\end{array}\right],
$$

where $\left[K_{1}\right]$ and $\left[K_{2}\right]$ are the stiffness matrices for the adjacent Buildings 1 and 2, respectively; and $\left[K_{\mathrm{d}}\right]$ is as explained in eq (2). The null matrices $\left[\mathrm{O}_{3}\right]$ and $\left[\mathrm{O}_{4}\right]$ are of order $(l \times m-l)$. The null matrices $\left[O_{5}\right]$ and $\left[O_{6}\right]$ are of order $(m-l \times l)$. And the null matrix $\left[\mathrm{O}_{7}\right]$ is of order $(m-l \times m-l)$. The damping matrix for the connected system is expressed as

$$
[C]=\left[\begin{array}{ll}
{\left[C_{1}\right]} & {\left[O_{1}\right]} \\
{\left[O_{2}\right]} & {\left[C_{2}\right]}
\end{array}\right]+\left[\begin{array}{rrr}
{\left[C_{\mathrm{d}}\right]} & -\left[C_{\mathrm{d}}\right] & {\left[O_{3}\right]} \\
-\left[C_{\mathrm{d}}\right] & {\left[C_{\mathrm{d}}\right]} & {\left[O_{4}\right]} \\
{\left[O_{5}\right]} & {\left[O_{6}\right]} & {\left[O_{7}\right]}
\end{array}\right]
$$

where $\left[C_{1}\right]$ and $\left[C_{2}\right]$ are the damping matrices for the adjacent Buildings 1 and 2, respectively; and $\left[C_{\mathrm{d}}\right]$ is as explained in eq (3). The bearing force vector for the combined system is

$$
\{F\}=\left\{\begin{array}{l}
\left\{F_{\mathrm{b}_{1}}\right\} \\
\left\{F_{\mathrm{b}_{2}}\right\}
\end{array}\right\} .
$$


The isolation layer forces $\left\{F_{\mathrm{b} 1}\right\}$ and $\left\{F_{\mathrm{b} 2}\right\}$ for three different types of isolation systems used in the present study such as high-damping rubber bearings, leadrubber bearings and friction pendulum systems under the adjacent buildings are derived as follows.

\subsection{High-damping rubber bearing}

The high-damping rubber bearing (HDRB) represents the commonly used elastomeric bearings. The basic components of HDRB are steel and rubber plates built in the alternate layers $[16,17]$. The dominant feature of HDRB is the parallel action of linear spring and damping as shown schematically in Fig 2(a). The HDRB exhibits high-damping capacity, horizontal flexibility and high vertical stiffness. The damping constant of the system varies considerably with the strain level of the bearing (generally of the order of $10 \%$ ). The system operates by decoupling the structure from the horizontal components of earthquake ground motion by interposing a layer of low horizontal stiffness between the structure and its foundation. The isolation effects in this type of system

are produced not by absorbing the earthquake energy, but by deflecting through the system dynamics. Usually, there is a large difference in the damping of structure and the isolation device, which makes the system nonclassically damped. The restoring force $F_{\mathrm{b}}$ developed in the HDRB is given by

$$
F_{\mathrm{bi}}=c_{\mathrm{bi}} \dot{x}_{\mathrm{bi}}+k_{\mathrm{bi}} x_{\mathrm{bi}} \quad(i=1,2),
$$

where $c_{\mathrm{bi}}$ and $k_{\mathrm{bi}}$ are damping and stiffness of HDRB, respectively.

The stiffness and damping of the HDRB are selected to provide the specific values of the two parameters characterising the system namely the isolation time pe$\operatorname{riod}\left(T_{\mathrm{bi}}\right)$ and damping ratio $\left(\xi_{\mathrm{bi}}\right)$ defined as

$$
\begin{gathered}
T_{\mathrm{bi}}=2 \pi \sqrt{\frac{M_{\mathrm{i}}}{k_{\mathrm{bi}}}} \quad(i=1,2), \\
\xi_{\mathrm{bi}}=\frac{c_{\mathrm{bi}}}{2 M_{\mathrm{i}} \omega_{\mathrm{bi}}} \quad(i=1,2),
\end{gathered}
$$

where $\omega_{\mathrm{bi}}=2 \pi / T_{\mathrm{bi}}$ is the isolation frequency.
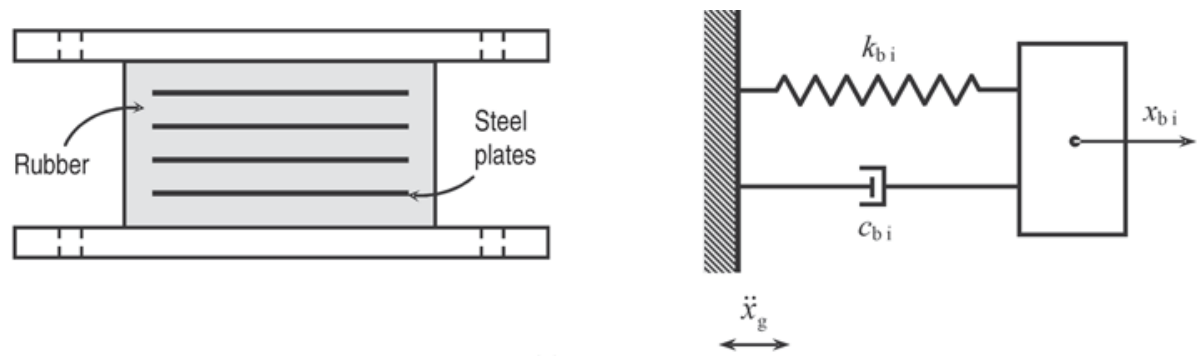

(a) HDRB
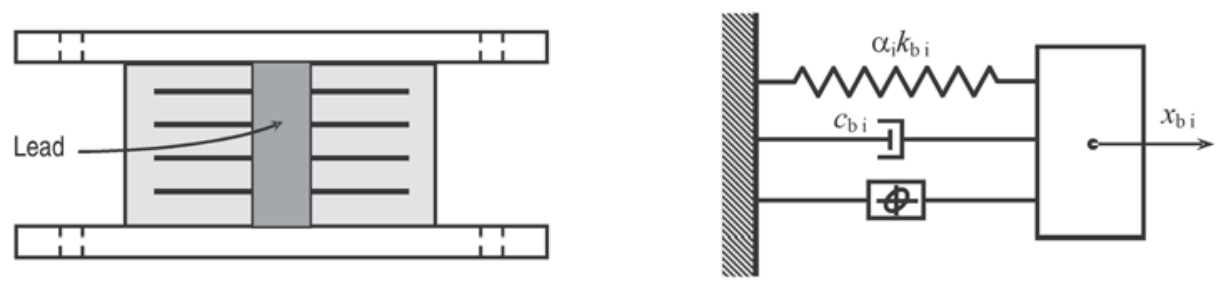

(b) LRB
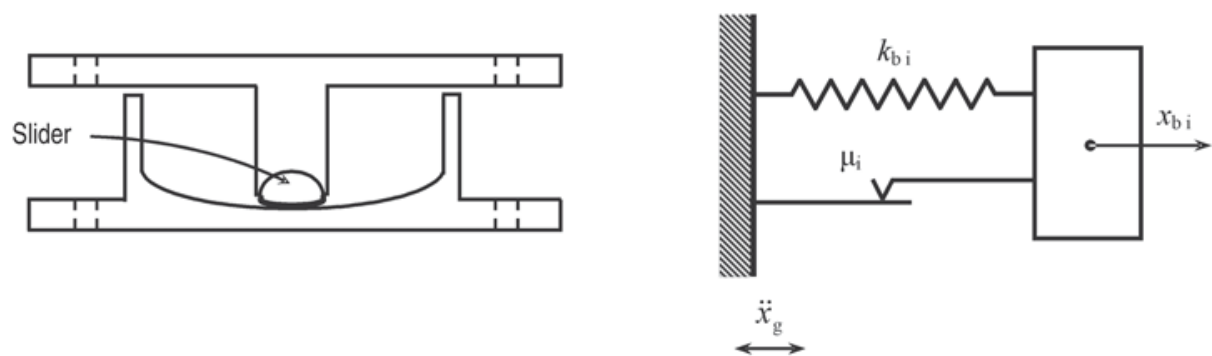

(c) FPS

Fig 2. Schematic models of isolation systems (a) HDRB; (b) LRB; and (c) FPS 


\subsection{Lead-rubber bearing}

The second category of elastomeric bearings is leadrubber bearings [18], as shown schematically in Fig 2(b). This system provides the combined features of vertical load support, horizontal flexibility, restoring force and damping in a single unit. These bearings are similar to the HDRB but a central lead core is used to provide an additional means of energy dissipation. The energy absorbing capacity by the lead-core reduces the lateral displacements of the isolator. The force-deformation behaviour of the LRB is generally represented by nonlinear characteristics following a hysteretic nature. For the present study, Wen's model [19] is used to characterise the hysteretic behaviour of the LRB. The restoring force developed in these isolation systems is given by

$$
F_{\mathrm{bi}}=c_{\mathrm{bi}} \dot{x}_{\mathrm{bi}}+\alpha_{\mathrm{i}} k_{\mathrm{i}} x_{\mathrm{bi}}+\left(1-\alpha_{\mathrm{i}}\right) F_{\mathrm{yi}} Z_{\mathrm{i}} \quad(i=1,2),
$$

where $F_{\mathrm{yi}}$ is the yield strength of the bearing; $\alpha_{\mathrm{i}}-$ an index which represents the ratio of post-to pre-yielding stiffness; $k_{\mathrm{i}}$ - the initial stiffness of the bearing; $c_{\mathrm{bi}}-$ the viscous damping of the bearing; and $Z_{\mathrm{i}}$ is the nondimensional hysteretic displacement component satisfying the following non-linear first order differential equation expressed as

$$
q_{\mathrm{i}} \frac{d Z_{\mathrm{i}}}{d t}=A \dot{x}_{\mathrm{bi}}+\beta\left|\dot{x}_{\mathrm{bi}}\right| Z_{\mathrm{i}}\left|Z_{\mathrm{i}}\right|^{\mathrm{n}-1}-\tau \dot{x}_{\mathrm{bi}}\left|Z_{\mathrm{i}}\right|^{\mathrm{n}} \quad(i=1,2),
$$

where $q_{\mathrm{i}}$ is the isolator yield displacement; dimensionless parameters $A, \beta, \tau$ and $n$ are selected such that the predicted response from the model closely matches the experimentally obtained results. The parameter $n$ is an integer constant, which controls smoothness of the transition from elastic to plastic response.

The LRB is characterised by the isolation period $\left(T_{\mathrm{bi}}\right)$, damping ratio $\left(\xi_{\mathrm{bi}}\right)$ and normalized yield strength, $Q_{\mathrm{i}}$ ie $Q_{\mathrm{i}}=F_{\mathrm{yi}} / W_{\mathrm{i}}$ (where $W_{\mathrm{i}}=M_{\mathrm{i}} g$ is the total weight of the building; and $g$ is the acceleration due to gravity). The bearing parameters $T_{\mathrm{bi}}$ and $\xi_{\mathrm{bi}}$ are computed from eqs (14) and (15) respectively, using the post-yield stiffness of the bearing. Other parameters of the LRB are held constant with $q_{\mathrm{i}}=2,5 \mathrm{~cm}, A=1, \beta=\tau=0,5$ and $n=2$.

\subsection{Friction pendulum system}

One of the most popular and effective techniques for seismic isolation is the use of sliding isolation devices. The sliding systems exhibit an excellent performance under a variety of severe earthquake loading and are very effective in reducing large levels of the superstructure acceleration. These isolators are characterised by insensitivity to the frequency content of earthquake excitation, because of the tendency of a sliding system to reduce and spread the earthquake energy over a wide range of frequencies. Another advantage of sliding isolation systems over conventional rubber bearings is the development of the frictional force at the base; it is proportional to the mass of the structure, and the centre of mass and centre of resistance of the sliding support coincides. Consequently, the torsional effects produced by the asymmetric building are diminished. The concept of sliding bearings is combined with the concept of a pendulum type response, resulting in a conceptually interesting seismic isolation system known as a friction pendulum system (FPS) [20] as shown schematically in Fig 2(c). In FPS, the isolation is achieved by means of an articulated slide on spherical, concave chrome surface. The slide is faced with a bearing material which, when in contact with the polished chrome surface, results in friction force, while concave surface produces restoring force. The resisting force provided by the FPS is

$$
F_{\mathrm{bi}}=k_{\mathrm{bi}} x_{\mathrm{bi}}+F_{\mathrm{xi}} \quad(i=1,2)
$$

where $k_{\mathrm{bi}}$ is the bearing stiffness provided by virtue of inward gravity action at the concave surface; $F_{\mathrm{x} i}$ is the frictional force at slide and polished chrome surface junction.

The system is characterised by a isolation time period $\left(T_{\mathrm{bi}}\right)$ that depends upon radius of curvature of concave surface and friction coefficient $\left(\mu_{\mathrm{i}}\right)$. The isolation stiffness $k_{\mathrm{bi}}$ is adjusted and the specified value of the isolation time period evaluated by the eq (14) is achieved.

\section{Solution of equations of motion}

Classical modal superposition technique cannot be employed in the solution of equations because the system is non-classically damped due to difference in damping in the isolation system as compared to the damping in the superstructure of a base-isolated building as well as the damper-links. Therefore, for different earthquakes, the equations of motion are solved numerically using Newmark's method of step-by-step integration; adopting linear variation of acceleration over a small time interval of $\Delta t$. The time interval for solving the equations of motion is taken as $0,02 / 20 \mathrm{sec}$ (ie $\Delta t=0,001 \mathrm{sec}$ ). At each time instant, the responses, namely the accelerations and displacements are obtained at each floor level of the two adjacent buildings.

\section{Numerical study}

The seismic response of two adjacent multi-storied buildings, connected using viscoelastic dampers, either both or one of them supported on isolation devices is investigated here. The multi-degree-of-freedom shear models of the adjacent buildings are used, with linear viscoelastic damping devices at different floor levels. The earthquake motions selected for this study are (i) $\mathrm{N} 00 \mathrm{E}$ component of 1989 Loma Prieta earthquake (18 Oct 1989) recorded at Los Gatos Presentation Centre; (ii) N90S component of 1994 Northridge earthquake (17 Jan 1994) recorded at Sylmar Converter station; and (iii) N00S component of 1995 Kobe earthquake (17 Jan 1995) 
recorded at JMA. The peak ground acceleration (PGA) of Loma Prieta, Northridge and Kobe earthquake motions are $0,56 \mathrm{~g}, 0,59 \mathrm{~g}$ and $0,82 \mathrm{~g}$, respectively.

\subsection{Two viscoelastic damper connected to adjacent base-isolated buildings}

The time histories of top floor acceleration, bearing displacement and damper displacement for 3 and 5-storied adjacent base-isolated buildings using HDRB $\left(T_{\mathrm{b} 1}=2 \mathrm{sec}\right.$ and $\left.\xi_{\mathrm{b} 1}=0,1\right)$ and LRB $\left(T_{\mathrm{b} 2}=3 \mathrm{sec}\right.$, $\xi_{\mathrm{b} 2}=0,05, q_{2}=2,5 \mathrm{~cm}$ and $\left.Q_{2}=0,05\right)$ respectively, for unconnected and connected cases under 1989 Loma Prieta earthquake are plotted in Fig 3. The associated response with the non-isolated response of the buildings for the purpose of comparison is also shown. The total external normalised stiffness of $\kappa_{d}=1$ and total external normalised damping of $\eta_{d}=2$ is chosen with damper connections provided at all the floors having equal values of stiffness and damping coefficients. The values of $\kappa_{d}$ and $\eta_{d}$ equal to 1 and 2 indicate respectively that the damper-stiffness is equal to that provided by the typical rubber bearing, and damping is double. It is observed that the bearing displacement in the base-isolated Building $1,\left(x_{\mathrm{b} 1}\right)$ and the adjacent base-isolated Building 2, $\left(x_{\mathrm{b} 2}\right)$ has decreased largely when connected by viscoelastic dampers. The top floor acceleration in isolated Building 1, $\left(\ddot{x}_{l 1}\right)$ with HDRB decreased substantially, and Building 2, $\left(\ddot{x}_{m 2}\right)$ with LRB are increased marginally when these two buildings are connected together. Similarly, response time histories for 3 and 5 -storied adjacent base-isolated buildings using LRB $\left(T_{\mathrm{b} 1}=2 \mathrm{sec}\right.$, $\xi_{\mathrm{b} 1}=0,05, \quad q_{1}=2,5 \mathrm{~cm}$ and $\left.Q_{1}=0,05\right)$ and FPS $\left(T_{\mathrm{b} 2}=3 \mathrm{sec}\right.$ and $\left.\mu_{2}=0,05\right)$, respectively for different cases under Loma Prieta, 1989 earthquake are plotted in Fig 4. The trend of results obtained here also shows the seismic response reduction, particularly in reducing the excessive displacements at isolation level associated with insignificant increase of superstructure acceleration in
Building 2. Additionally, it is seen in both the above cases that the isolation effectiveness is decreased to some extent because of damper linkages, as evident in the increased number of vibration cycles of the acceleration time history. It is concluded from the above observations that the connection of the adjacent base-isolated buildings with viscoelastic dampers leads to substantial reduction in seismic response or marginal increase in it during earthquake motion. However, the crucial advantage obtained through these linkages is in avoiding the pounding damages at the floors, especially at base mass. The reduction in peak bearing displacement prevents the isolator damages arising due to instability at large displacements or pounding with adjacent ground structures during earthquakes.

Table 1 shows the peak response of unconnected and connected adjacent base-isolated buildings for $\kappa_{d}=1$ and $\eta_{d}=2$ distributed equally amongst all the dampers. For the purpose of demonstration, a 3-storied base-isolated Building 1 mounted on different isolators is considered adjacent to the other 5-storied base-isolated Building 2 isolated using different isolators, with the isolation parameters same as mentioned earlier. Note that the isolation time periods of the adjacent Building 1, $T_{\mathrm{b} 1}=2 \mathrm{sec}$ and Building $2, T_{\mathrm{b} 2}=3 \mathrm{sec}$ are taken. Performance of these two buildings is observed during the cases such as (a) non-isolated, (b) isolated-unconnected and (c) isolated-connected at all floors using viscoelastic dampers with equal distribution of total external damping amongst all the dampers. When viscoelastic damper links are introduced, generally the bearing displacement in both the base-isolated Buildings 1 and 2 decreases compared to the unconnected case. The effect of damper linkages is found more on the bearing displacement as compared to that on the top floor acceleration. The top floor acceleration in these adjacent buildings decreases, while in few cases it may be found to increase marginally for the selected externally added stiffness and damping. For this reason, it is to be noted that the selection

Table 1. Peak response of unconnected and viscoelastic damper connected adjacent base-isolated buildings $\left(\kappa_{d}=1, \eta_{d}=2\right)$

\begin{tabular}{|c|c|c|c|c|c|c|c|}
\hline \multirow{2}{*}{\multicolumn{2}{|c|}{$\begin{array}{c}\text { Observation Quantity } \\
\text { Isolation system } \\
\text { 3-story Building } 1 \\
\text { 5-story Building } 2\end{array}$}} & \multicolumn{2}{|c|}{ Loma Prieta, 1989} & \multicolumn{2}{|c|}{ Northridge, 1994} & \multicolumn{2}{|c|}{ Kobe, 1995} \\
\hline & & $\begin{array}{c}\text { Bearing } \\
\text { displacement } \\
(\mathrm{cm})\end{array}$ & $\begin{array}{l}\text { Top floor } \\
\text { acceleration } \\
\quad(g)\end{array}$ & $\begin{array}{c}\text { Bearing } \\
\text { displacement } \\
(\mathrm{cm})\end{array}$ & $\begin{array}{c}\text { Top floor } \\
\text { acceleration } \\
(g)\end{array}$ & $\begin{array}{c}\text { Bearing } \\
\text { displacement } \\
(\mathrm{cm})\end{array}$ & $\begin{array}{c}\text { Top floor } \\
\text { acceleration } \\
(g)\end{array}$ \\
\hline \multirow{4}{*}{ Unconnected } & 3-story HDRB & 53,38 & 0,550 & 34,34 & 0,362 & 31,90 & 0,348 \\
\hline & 3-story LRB & 53,08 & 0,565 & 29,93 & 0,333 & 34,89 & 0,393 \\
\hline & 5-story LRB & 60,56 & 0,380 & 37,47 & 0,255 & 28,95 & 0,252 \\
\hline & 5-story FPS & 63,88 & 0,436 & 30,39 & 0,426 & 25,30 & 0,464 \\
\hline \multirow{6}{*}{ Connected } & Building 1 HDRB & 47,00 & 0,333 & 37,41 & 0,263 & 26,50 & 0,202 \\
\hline & Building 2 LRB & 53,57 & 0,425 & 42,39 & 0,351 & 29,49 & 0,241 \\
\hline & Building 1 HDRB & 46,05 & 0,330 & 35,43 & 0,242 & 24,50 & 0,193 \\
\hline & Building 2 FPS & 52,95 & 0,443 & 40,21 & 0,374 & 27,07 & 0,346 \\
\hline & Building 1 LRB & 46,95 & 0,325 & 34,96 & 0,254 & 23,34 & 0,195 \\
\hline & Building 2 FPS & 53,75 & 0,443 & 39,97 & 0,401 & 26,25 & 0,329 \\
\hline \multirow{2}{*}{ Non-isolated } & 3-story Building & \multirow{2}{*}{-} & 2,393 & \multirow{2}{*}{-} & 1,843 & \multirow{2}{*}{-} & 2,076 \\
\hline & 5-story Building & & 2,710 & & 1,965 & & 3,558 \\
\hline
\end{tabular}




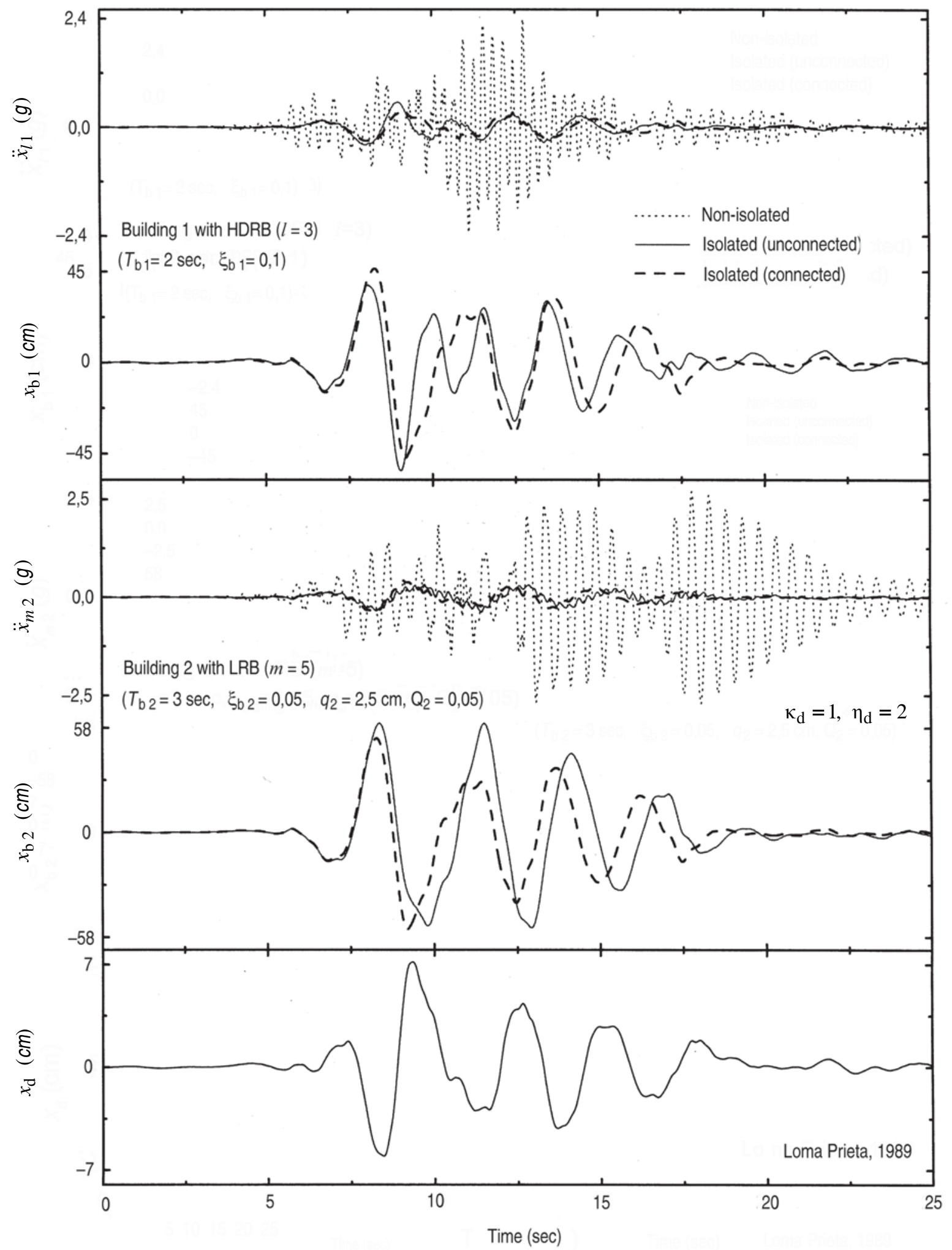

Fig 3. Time history for top floor acceleration and bearing displacement for 3 and 5 -storied adjacent base-isolated buildings using HDRB and LRB, respectively under Loma Prieta, 1989 earthquake 


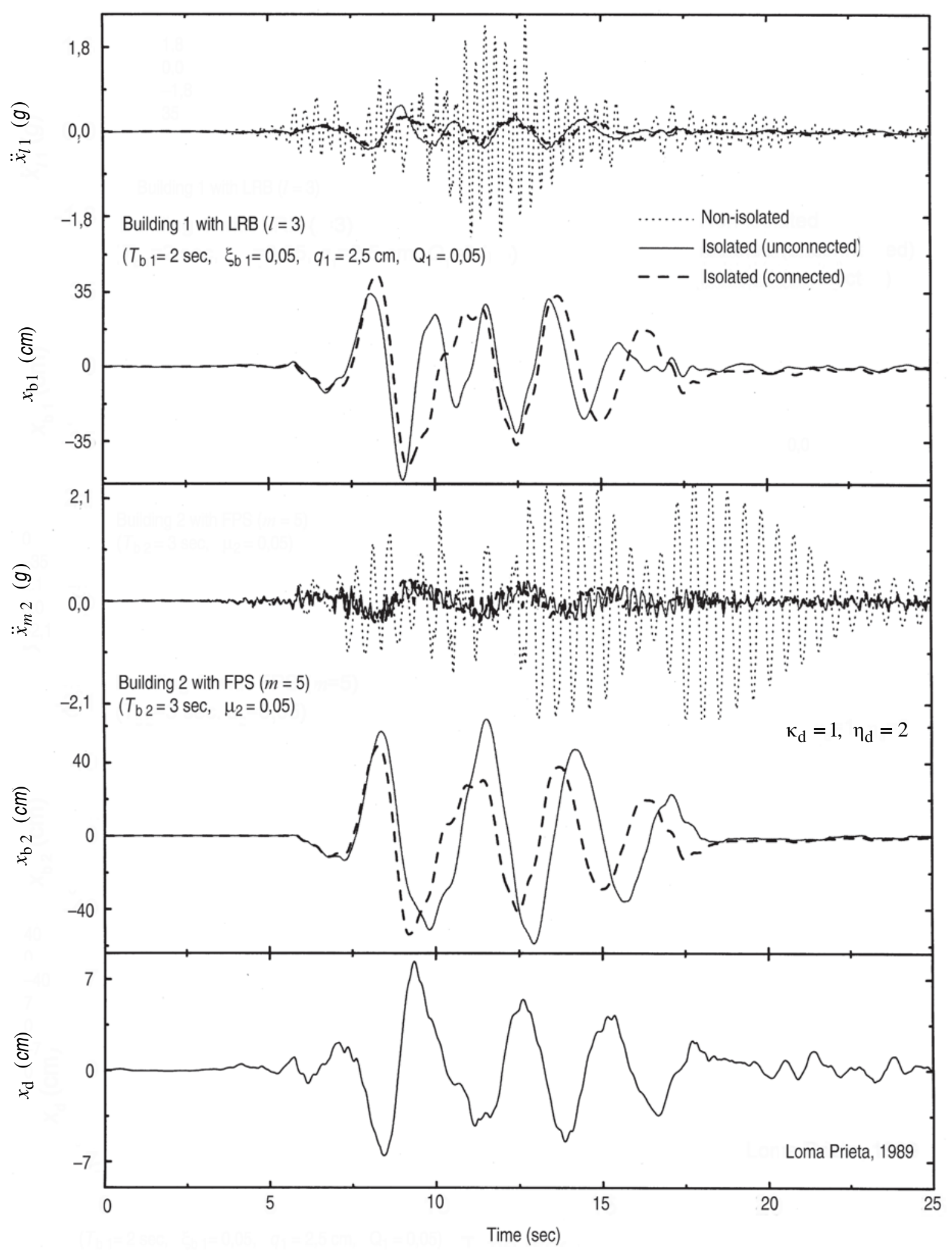

Fig 4. Time history for top floor acceleration and bearing displacement for 3 and 5-storied adjacent base-isolated buildings using LRB and FPS, respectively under Loma Prieta, 1989 earthquake 
of proper values of damper-stiffness, damper-damping and distribution pattern along the height of the connected system is highly essential to obtain the maximum seismic response reduction. In few cases, the individual bearing displacement values may increase with the introduction of damper connections, especially for stiffer buildings, however the peak displacement of the combined system (ie $x_{\mathrm{b} 1}+x_{\mathrm{b} 2}$ ) reduces considerably as compared to the sum of bearing displacements of these two adjacent base-isolated buildings in the unconnected case. This reduction in peak bearing displacement helps in reduced chances of the isolated building system to collide upon the ground structures on either side of the buildings such as retaining walls, entrance ramps etc. In no case, however, the top floor acceleration in the isolated building is found to increase than that in case of the corresponding non-isolated Building $1\left(T_{\mathrm{s}}=0,3 \mathrm{sec}\right.$ and $\left.\xi_{\mathrm{s}}=0,02\right)$ and Building $2\left(T_{\mathrm{s}}=0,5 \mathrm{sec}\right.$ and $\left.\xi_{\mathrm{s}}=0,02\right)$.

\subsection{Viscoelastic damper connected to adjacent base- isolated and fixed-base buildings}

The time histories of top floor acceleration and bearing displacement for 4-storied base-isolated building supported on HDRB $\left(T_{\mathrm{b} 1}=2 \mathrm{sec}\right.$ and $\left.\xi_{\mathrm{b} 1}=0,1\right)$ adjacent to a 6-story fixed-base building $\left(T_{\mathrm{s} 2}=0,6 \mathrm{sec}\right.$ and $\xi_{\mathrm{s} 2}=0,02$ ) excited by the Loma Prieta, 1989 earthquake, unconnected and connected by viscoelastic dampers are plotted in Fig 5. The connecting links are provided at all the corresponding adjacent floors of fixed-base and isolated building with $\kappa_{\mathrm{d}}=0,8$ and $\eta_{\mathrm{d}}=1,5$ distributed equally amongst all the dampers. It is observed that there is a substantial reduction in the bearing displacement of the base-isolated building and the top floor acceleration in the fixed-base building. The top floor acceleration of the base-isolated building increased marginally, however those are still far less than its non-isolated counterpart. Comparison between Figs 3, 4 and 5 reveal that the effectiveness of viscoelastic damper links to connect the adjacent buildings is more when the adjacent structures are base-isolated and fixed-base buildings. It is the most advantageous, because the seismically under-designed conventional structures of vital strategic importance can be seismically retrofitted through such damper connection scheme without any other strengthening measures required to the original structure, provided the adjacent structure is base-isolated.

Similar observations of reduction in seismic response can be made from Table 2 when base-isolated building and adjacent fixed-base building are connected by viscoelastic dampers. Here the peak values of seismic response is shown for 4-storied base-isolated building mounted on different isolation systems adjacent to 6-story fixed-base building excited by different earthquakes, unconnected and connected using viscoelastic dampers. Note, that the time periods of the adjacent Building 1, $T_{\mathrm{b} 1}=2 \mathrm{sec}$ and Building 2, $T_{\mathrm{s} 2}=0,6 \mathrm{sec}$ are taken while keeping rest of the isolation properties similar as before. The connecting links are provided at all the corresponding adjacent floors of fixed-base and isolated building with $\kappa_{d}=0,8$ and $\eta_{d}=1,5$ distributed equally amongst all the dampers. Similar trend of seismic response reduction is observed with incorporation of damper linkages; in particular, the response reduction in original fixed-base structure is seen substantial. Nevertheless, from the comparison of Table 1 and 2 it can be concluded that the effectiveness of use of damper connections for adjacent base-isolated and fixed-base building is more than the two connected adjacent base-isolated buildings.

\subsection{Effect of stiffness of viscoelastic damper}

As it is seen in the time history of acceleration of connected systems, the number of cycles of vibration increases when dampers are introduced. It is essential to study the effect of stiffness of viscoelastic dampers on the seismic response. Fig 6 shows a comparison of corresponding FFT amplitude spectra of the top floor acceleration for three different cases under Loma Prieta,

Table 2. Peak response of unconnected and viscoelastic damper connected adjacent base-isolated and fixed-base buildings $\left(\kappa_{\mathrm{d}}=0,8, \eta_{\mathrm{d}}=1,5\right)$

\begin{tabular}{|c|c|c|c|c|c|c|c|}
\hline \multirow{2}{*}{\multicolumn{2}{|c|}{$\begin{array}{c}\text { Observation Quantity } \\
\text { Isolation system } \\
\text { 4-story Building } 1 \\
\text { 6-story Building } 2\end{array}$}} & \multicolumn{2}{|c|}{ Loma Prieta, 1989} & \multicolumn{2}{|c|}{ Northridge, 1994} & \multicolumn{2}{|c|}{ Kobe, 1995} \\
\hline & & $\begin{array}{c}\text { Bearing } \\
\text { displacement } \\
(\mathrm{cm})\end{array}$ & $\begin{array}{c}\text { Top floor } \\
\text { acceleration } \\
(g)\end{array}$ & $\begin{array}{c}\text { Bearing } \\
\text { displacement } \\
(\mathrm{cm})\end{array}$ & $\begin{array}{c}\text { Top floor } \\
\text { acceleration } \\
(g)\end{array}$ & $\begin{array}{c}\text { Bearing } \\
\text { displacement } \\
(\mathrm{cm})\end{array}$ & $\begin{array}{c}\text { Top floor } \\
\text { acceleration } \\
(g)\end{array}$ \\
\hline \multirow{3}{*}{ Unconnected } & 4-story HDRB & 53,27 & 0,560 & 34,54 & 0,362 & 31,34 & 0,358 \\
\hline & 4-story LRB & 52,97 & 0,569 & 30,07 & 0,339 & 34,32 & 0,404 \\
\hline & 4-story FPS & 52,05 & 0,641 & 31,94 & 0,482 & 30,60 & 0,416 \\
\hline \multirow{6}{*}{ Connected } & Building 1 HDRB & 18,82 & 0,689 & 16,36 & 0,594 & 23,33 & 0,830 \\
\hline & Building 2 Fixed & - & 1,585 & - & 1,410 & - & 1,520 \\
\hline & Building 1 LRB & 19,34 & 0,742 & 1,405 & 0,631 & 24,65 & 0,935 \\
\hline & Building 2 Fixed & - & 1,571 & - & 16,58 & - & 1,524 \\
\hline & Building 1 FPS & 18,82 & 0,791 & 17,03 & 0,636 & 25,23 & 1,061 \\
\hline & Building 2 Fixed & - & 1,640 & - & 1,480 & - & 1,498 \\
\hline \multirow{2}{*}{ Non-isolated } & 4-story Building & \multirow{2}{*}{-} & 2,033 & \multirow{2}{*}{-} & 1,648 & \multirow{2}{*}{-} & 3,524 \\
\hline & 6-story Building & & 2,982 & & 1,824 & & 2,562 \\
\hline
\end{tabular}




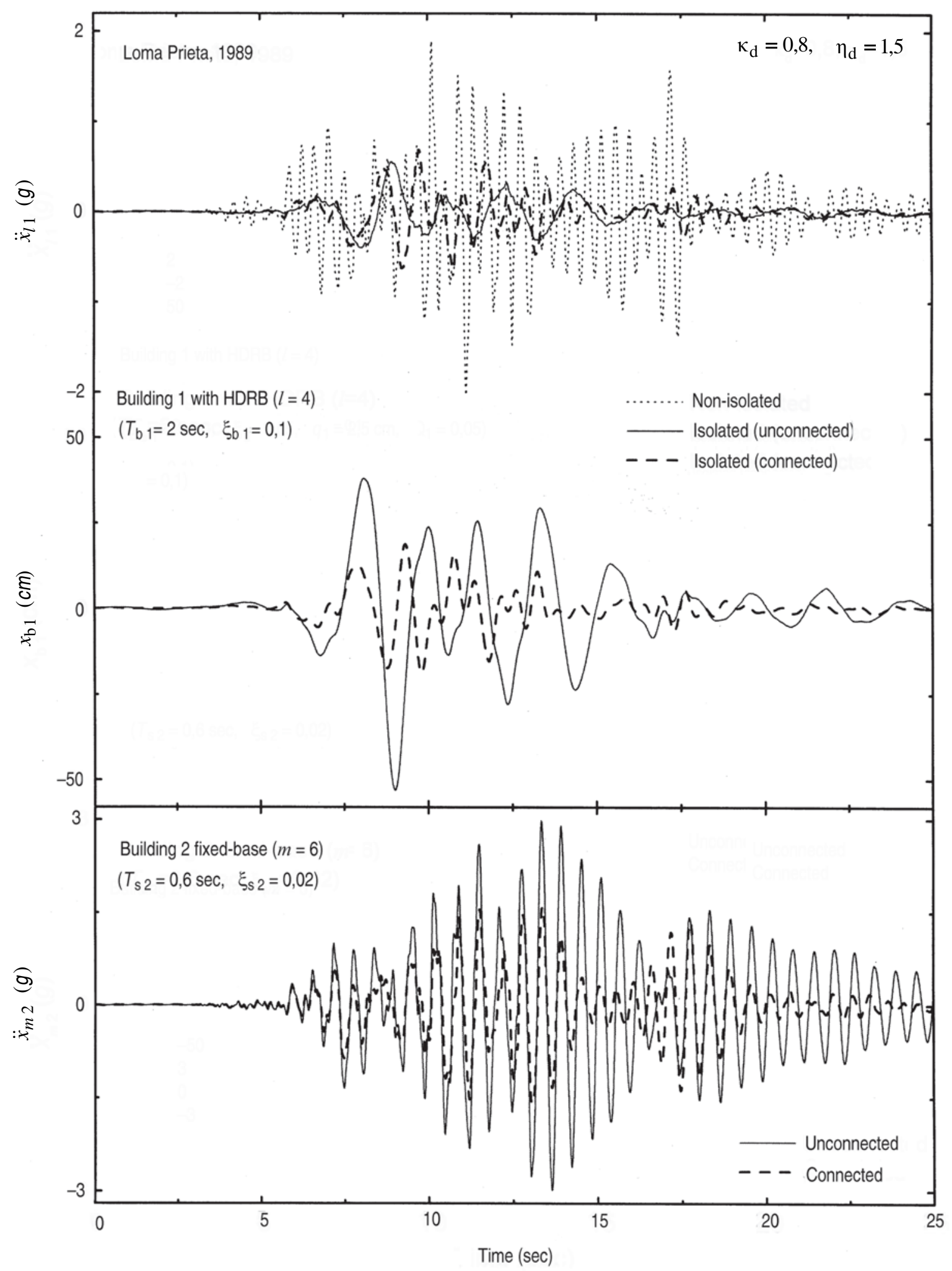

Fig 5. Time history for top floor acceleration and bearing displacement for 4-storied base-isolated building using HDRB and 6-storied fixed-base adjacent buildings under Loma Prieta, 1989 earthquake 

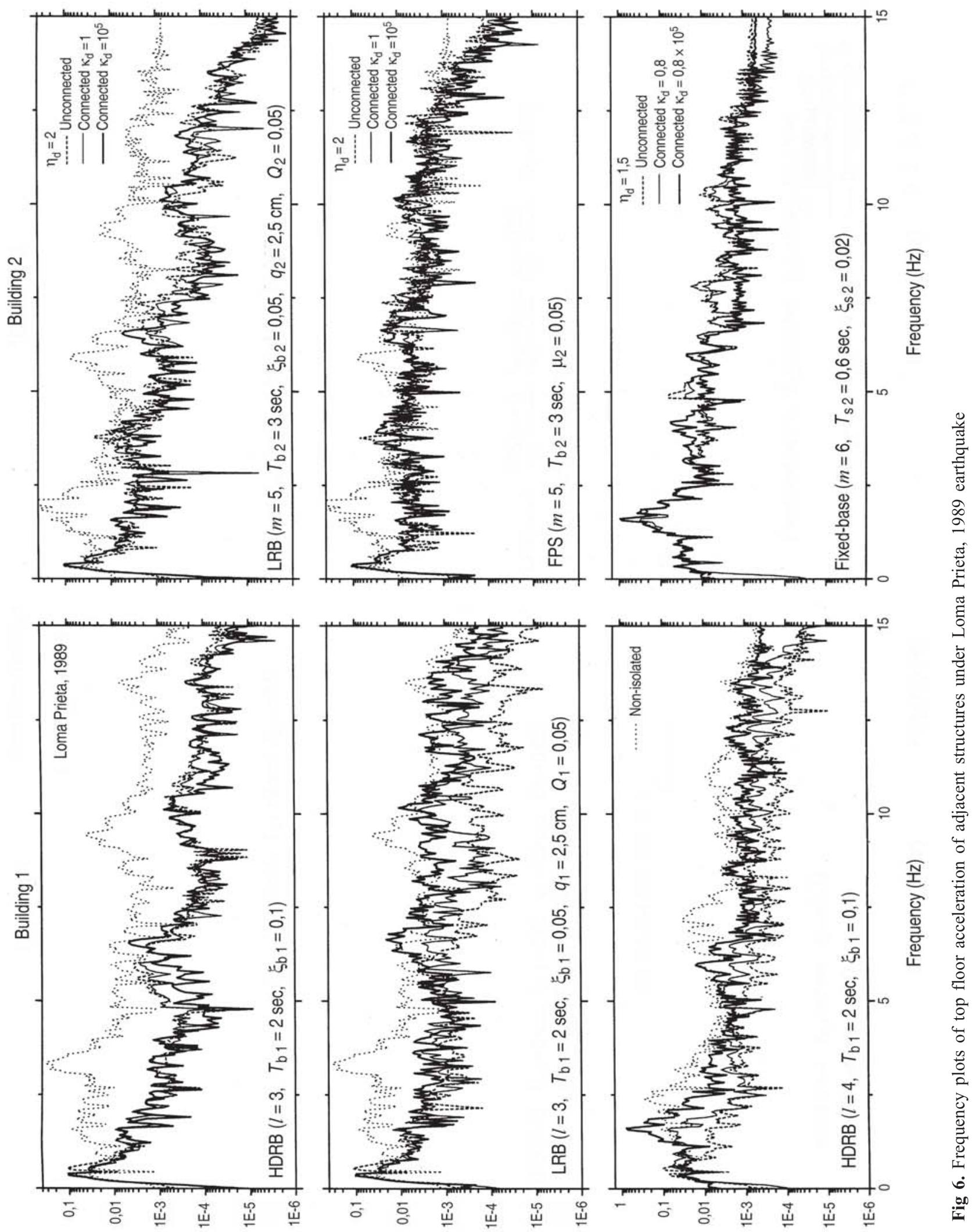

(6) әpn!!!due $\downarrow \unlhd$

(6) әpnџ!!dur $\downarrow ل$

(6) әрпџ!!dur $\perp \dashv \unlhd$

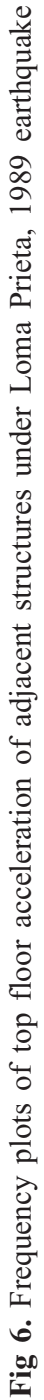

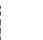


1989 earthquake ground motion (refer to Figs 3 to 5 for a corresponding time history of top floor acceleration). These results show that due to increase in stiffness of viscoelastic dampers the FFT amplitudes of top floor acceleration increases and it confirms the reduction in isolation effectiveness. There is an increase in the amplitude of FFT amplitudes associated with a high-frequency content. The acceleration increase associated with high frequency content can be detrimental to high-frequency equipment installed in a building. However, in case of the fixed-base building retrofitted through viscoelastic damper connections with increased stiffness values tends to reduce the FFT amplitudes, thereby enhancing the effectiveness of such damper linkages.

\section{Conclusions}

The seismic response of adjacent buildings connected with viscoelastic dampers is investigated, when both or one of the buildings is base-isolated. From the trend of the results of present study the following major conclusions can be drawn.

1. Significant reduction in the peak displacement is achieved by introducing viscoelastic damper connections at the floor levels of adjacent base-isolated buildings, helpful in avoiding the pounding consequences. Superstructure acceleration may increase marginally in few cases due to the introduction of dampers as connectors; nevertheless, it remains to a great extent lower than that in the corresponding non-isolated system.

2. The effectiveness of viscoelastic dampers as connecting linkages is found to be more significant in case of connected base-isolated and fixed-base buildings as compared to the two adjacent connected base-isolated buildings. This is advantageous in the retrofitting works of existing under-designed fixed-base structures.

3. Increase in the stiffness of viscoelastic damper leads to excitation of higher modes of vibration, which can be detrimental to the high-frequency equipment mounted on these structures.

\section{References}

1. Kelly, J. M. Aseismic base isolation: review and bibliography, Soil Dynamics and Earthquake Engineering, Vol 5, Issue 4, 1986, p. 202-216.

2. Buckle, I. G. and Mayes, R. L. Seismic isolation: history, application and performance - a world view. Earthquake Spectra, Vol 6, Issue 2, 1990, p. 161-201.

3. Jangid, R. S. and Datta, T. K. Seismic behaviour of baseisolated buildings: a state-of-the-art review, Structures and Buildings, Vol 110, Issue 2, 1995, p. 186-203.

4. Housner, G. W.; Bergman, L. A.; Caughey, T. K.; Chassiakos, A. G.; Claus, R. O.; Masri, S. F.; Skelton, R. E.; Soong, T. T.; Spencer, Jr. B. F. and Yao, J. T. P. Structural control: past, present and future, Journal of Engineering Mechanics (ASCE), Vol 123, Issue 9, 1997, p. $897-971$.
5. Soong, T. T. and Spencer, Jr. B. F. Supplemental energy dissipation: state-of-the-art and state-of-the-practice, Engineering Structures, Vol 24, Issue 3, 2002, p. 243-259.

6. Westermo, B. D. The dynamics of interstructural connection to prevent pounding, Earthquake Engineering and Structural Dynamics, Vol 18, Issue 5, 1989, p. 687-699.

7. Luco, J. E. and De Barros, F. C. P. Optimal damping between two adjacent elastic structures, Earthquake Engineering and Structural Dynamics, Vol 27, Issue 7, 1998, p. 649-659.

8. Xu, Y. L. and Zhang, W. S. Closed-form solution for seismic response of adjacent buildings with linear quadratic Gaussian controllers, Earthquake Engineering and Structural Dynamics, Vol 31, Issue 2, 2002, p. 235-259.

9. Xu, Y. L.; He, Q. and Ko, J. M. Dynamic response of damper-connected adjacent buildings under earthquake excitation, Engineering Structures, Vol 21, Issue 2, 1999 , p. 135-148.

10. Xu, Y. L.; Zhan, S.; Ko, J. M. and Zhang, W. S. Experimental investigation of adjacent buildings connected by fluid damper, Earthquake Engineering and Structural Dynamics, Vol 28, Issue 6, 1999, p. 609-631.

11. Ni, Y. Q.; Ko, J. M. and Ying, Z. G. Random seismic response analysis of adjacent buildings coupled with nonlinear hysteretic dampers, Journal of Sound and Vibration, Vol 246, Issue 3, 2001, p. 403-417.

12. Zhang, W. S. and $\mathrm{Xu}, \mathrm{Y}$. L. Dynamic characteristics and seismic response of adjacent buildings linked by discrete dampers, Earthquake Engineering and Structural Dynamics, Vol 28, Issue 10, 1999, p. 1163-1185.

13. Zhang, W. S. and Xu, Y. L. Vibration analysis of two buildings linked by Maxwell model-defined fluid dampers, Journal of Sound and Vibration, Vol 233, Issue 5, 2000, p. 775796.

14. Zhang, R. H. and Soong, T. T. Seismic design of viscoelastic dampers for structural applications, Journal of Structural Engineering (ASCE), Vol 118, Issue 5, 1992, p. 1375-1392.

15. Zhang, R. H.; Soong, T. T. and Mahmoodi, P. Seismic response of steel frame structures with added viscoelastic dampers, Earthquake Engineering and Structural Dynamics, Vol 18, Issue 3, 1989, p. 389-396.

16. Kikuchi, M. and Aiken, I. D. An analytical hysteresis model for elastomeric seismic isolation bearings. Earthquake Engineering and Structural Dynamics, Vol 26, Issue 2, 1997, p. 215-231.

17. Koo, G. H.; Lee, J. H.; Yoo, B. and Ohtori, Y. Evaluation of laminated rubber bearings for seismic isolation using modified macro-model with parameter equations of instantaneous apparent shear modulus. Engineering Structures, Vol 21, Issue 7, 1999, p. 594-602.

18. Robinson, W. H. Lead-rubber hysteretic bearings suitable for protecting structures during earthquakes, Earthquake Engineering and Structural Dynamics, Vol 10, Issue 4, 1982, p. 593-604.

19. Wen, Y. K. Method for random vibration of hysteretic systems, Journal of Engineering Mechanics Division (ASCE), Vol 102, Issue 2, 1976, p. 249-263.

20. Zayas, V. A.; Low, S. S. and Mahin, S. A. A simple pendulum technique for achieving seismic isolation, Earthquake Spectra, Vol 6, Issue 2, 1990, p. 317-333. 


\section{SEISMINEI IZOLIACIJAI SKIRTAS SU GRETIMU STATINIU SUJUNGTAS KLAMPIAI TAMPRUS SLOPINTUVAS}

\section{A. Matsagar, R. S. Jangid}

\section{Santrauka}

Tyrinejjamas daugiaaukščių statinių su įvairiomis izoliavimo sistemomis ir klampiai tampriais slopintuvais, sujungtais su kitais analogiškais statiniais, seisminis atsakas. Daugiaaukščiai pastatai modeliuoti šlyties tipo konstrukcijomis su skersiniais laisvès laipsniais kiekvienam aukštui. Aukštai sujungti skirtinguose lygiuose klampiai tampriais slopintuvais. Tokios sistemos laikysena tyrinèta sudarant pagrindines judejimo lygtis ir jas sprendžiant žingsnis po žingsnio taikant tiesioginio integravimo-Niumarko metodą. Apskaičiuota abiejų struktūrų viršutinio aukšto absoliučiojo pagreičio ir atramos poslinkio variacija tam, kad būtų nustatyta sujungtos sistemos laikysena ir jos efektyvumas. Nustatyta, kad naudinga jungti gretimus izoliuotus pastatus klampiai tampriais slopintuvais siekiant mažinti didelius atramų poslinkius ir kartu išvengti izoliatorių pažeidimų dèl žemės drebejjimų. Nustatyta, kad jungtis taikant klampiai tamprius slopintuvus yra pati efektyviausia, kai gretimi pastatai yra su izoliuotomis bei fiksuotomis atramomis. Todẻl šis būdas naudingas gerinant fiksuotų atramu pastatu seismini atsparumą, kai jie yra šalia pastatų su izoliuotomis atramomis.

Raktažodžiai: gretimi pastatai, žemès drebejjimas, elastomerinė atrama, seisminis pagrindo izoliavimas, slankioji sistema, renovacija, klampiai tamprus slopintuvas.

Dr Vasant A. MATSAGAR is presently Post-doctoral Research Fellow and Adjunct Professor at the Dept of Civil Engineering at Lawrence Technological University, Michigan (USA). He received his PhD degree from Indian Institute of Technology Bombay (India) in 2005 for his research in the aseismic design of structures using passive seismic control devices. After graduating from the Government College of Engineering, Aurangabad (India) in 1997, he obtained his Master degree in Structural Engineering from the University of Pune (India) in 1998. He has three years' field experience in the analysis and design of structures. His present area of research includes static and dynamic response evaluation of the carbon fibre reinforced bridge structures.

Dr R. S. JANGID is Associate Professor at the Dept of Civil Engineering at Indian Institute of Technology Bombay, India. He received BE (Hons) in Civil Engineering from the University of Jodhpur (India) in 1989, and his M Tech and $\mathrm{PhD}$ in Structural Engineering from Indian Institute of Technology Delhi (India) in 1991 and 1993, respectively. His research interest includes the aseismic design of structures using active and passive control devices and the dynamic analysis of non-classically damped systems. His recent research contribution includes the base isolation for near-fault motions and its application to the bridges and tanks, multiple tuned mass dampers for vibration control and active control of torsionally coupled structures. 